\title{
Characterization and Beneficiation of an Egyptian Nepheline Syenite Ore
}

\author{
Abdel-Zaher M. Abouzeid and Abdel-Tawab A. Negm \\ Department of Mining, Faculty of Engineering, Cairo University, Giza 12613, Egypt \\ Correspondence should be addressed to Abdel-Zaher M. Abouzeid; abdel.abouzeid@gmail.com
}

Received 15 August 2013; Accepted 15 December 2013; Published 16 February 2014

Academic Editor: Makoto Arima

Copyright (C) 2014 A.-Z. M. Abouzeid and A.-T. A. Negm. This is an open access article distributed under the Creative Commons Attribution License, which permits unrestricted use, distribution, and reproduction in any medium, provided the original work is properly cited.

\begin{abstract}
Nepheline syenite ore is an essential constituent in ceramics and glass raw material meals, as a flux and as a source of alumina. The natural nepheline syenite rocks contain some undesired minerals, which are usually eliminated or reduced to the allowable limits by beneficiation. The present paper is concerned with characterization and beneficiation of an Egyptian nepheline syenite rock, at Abu Khruq locality, Eastern Desert, Egypt. The ore is exceptionally hard, with high crushing strength of $875 \mathrm{~kg} / \mathrm{cm}^{2}$, and iron oxide content of about $6.5 \%$. The grain size of the constituents is relatively large. In some samples, the iron oxides are disseminated within the feldspars and nepheline syenite crystals, or in cracks and fissures within the feldspars crystals. The rock contains some environmental hazardous elements such as uranium, thorium, and radon. Magnetic separation and flotation techniques were applied, separately or in combination. Under optimum operating conditions, magnetic separation followed by reverse anionic flotation gave a concentrate assaying $0.2 \% \mathrm{Fe}_{2} \mathrm{O}_{3}$ and about $24 \% \mathrm{Al}_{2} \mathrm{O}_{3}$ at alumina recovery of about $80 \%$. The radioactive elements were reduced in the concentrate to lower levels than their levels in the original rock.
\end{abstract}

\section{Introduction}

Nepheline syenite is a light-colored alkaline igneous rock formed mainly of alkali feldspar and nepheline in appreciable amounts. It is similar in appearance to coarse-grained granite but characterized by absence of quartz. Nepheline syenite is an indispensible raw material in glass and ceramic industries. The low fusion point of nepheline syenite lowers the melting temperature of the mix, promoting faster melting, higher productivity, and fuel savings. In ceramics industry, the low fusibility temperature and high fluxing capacity of nepheline allow it to act as vitrifying agent by contributing an early glassy phase that binds other constituents of the mix. This permits lower flux content in the ceramic body, increases alumina content in the mix, lowers the firing temperature, and shortens firing schedules. Furthermore, nepheline syenite finds uses in the manufacture of paints and pigments as filler in paints, papers, rubbers, and plastics. It is also used in the manufacture of alumina, alkali carbonates, and Portland cement.
The major world commercial reserves of nepheline syenite ores are located mainly in the former USSR, Norway, Canada, Turkey, and Brazil $[1,2]$. The main producing countries of marketable nepheline syenite are Russia, Canada, and Norway, where their total production in 1995 reached 3.6 million tons [2]. Most of the Russian nepheline syenite production is consumed locally for the production of alumina.

Nepheline syenite, which contains no free silica (quartz), is used for the production of fillers and extenders in the area of plastics and paints, particularly when it is finely ground. Environmentally, it is less hazardous in handling and processing than other competing fillers and extenders.

The occurrence of nepheline syenite in Egypt is restricted to the intrusion of the phanerozoic postorogenic alkaline ring complexes scattered in the southern sector of the Eastern Desert along the Red Sea hills, in five main localities (Figure 1). These ring complexes form a circular igneous structures formed after magma solidification. The rocks in theses complexes are of the alkaline silica-free type of rocks. 


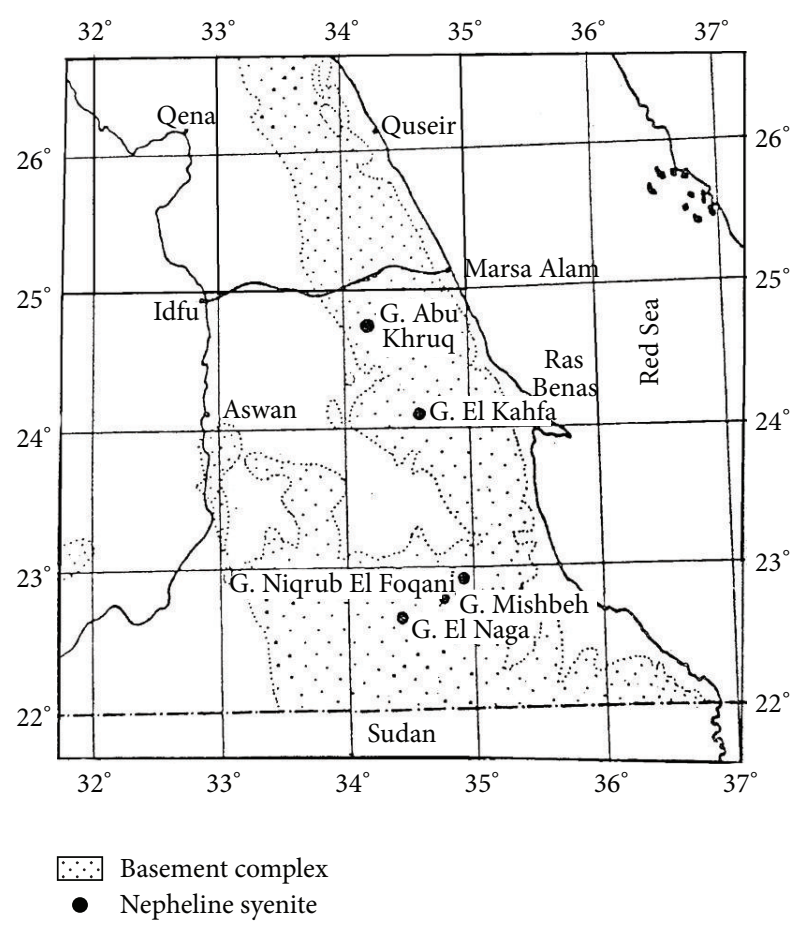

FIGURE 1: Key map of Nepheline Syenite locations.

These localities are limited by longitudes $34^{\circ}-36^{\circ} \mathrm{E}$ and latitudes $22^{\circ}-25^{\circ} \mathrm{N}[3,4]$. The largest reserves of these localities are at $\mathrm{Abu}$ Khruq area, where the probable reserve estimate is about 65 million tons [5]. The geographic coordinates of Abu Khruq area is at the intersection of longitude $34^{\circ} 08^{\prime} 18^{\prime \prime} \mathrm{N}$ and latitude $24^{\circ} 38^{\prime} 55^{\prime \prime} \mathrm{E}$ (Figure 1). Gebel Abu Khruq ring complex is formed of incomplete outer ring structure surrounding incomplete conical or stock-like intrusions forming the inner ring (Figures 2 and 3). Different tending shear zones cut across this ring structure (Figure 3 ). The outer ring is occupied by alkali syenites which are essentially of orthoclase pethite, albite, aegorite-augite, aegirine, ferrorichterie, biotite. The inner ring consists mainly of nepheline syenites which are characterized by gray color. Close to the main shear zones, the gray color changes to pinkish gray and red colors where the mineralization became ferroginated and stained by red colored iron-bearing (hydrothermal) solutions. Geologically, it has been shown that these ring complexes are tied to form a chain running along the zone of Great African faults which run in the Eastern zone of Africa [6].

Attempts were made to use Abu Khruq nepheline syenite ore for Alumina production. Experiments were carried out up to the semipilot scale. The process involves crushing and grinding of a mixture of nepheline syenite ore and limestone in a certain ratio, sintering the ground material, crushing and grinding the sinter product, digesting the ground sinter powder, filtering the slurry, desilicating the filtrate, and decomposition of the filtrate into alumina bearing part and alkali bearing liquor. The alumina bearing liquor is hydrolyzed, filtered, and calcined to produce a commercial alumina product. The alkali liquor is used for the production

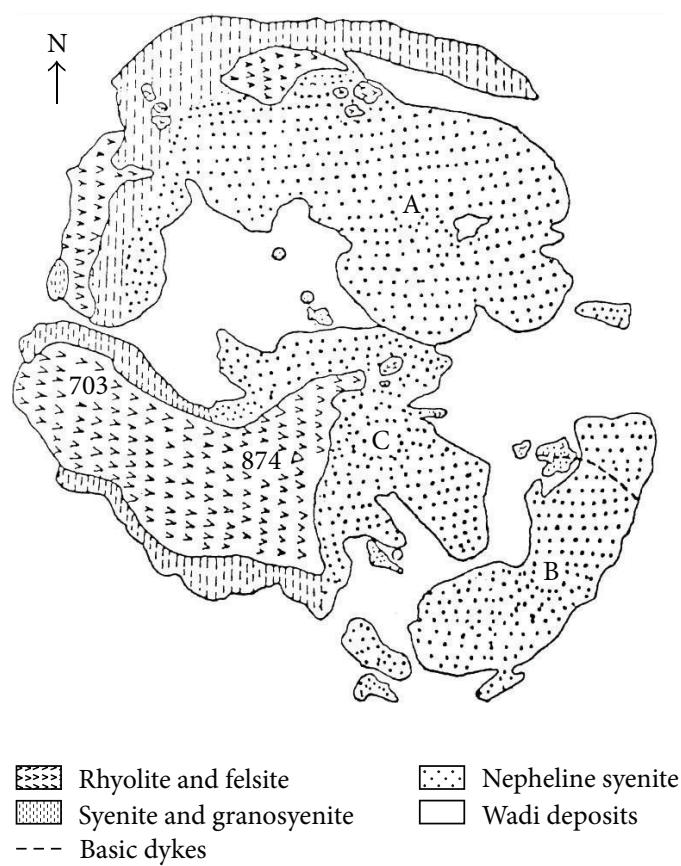

FIGURE 2: Sketch map of "Gabal-Abu Khruq" showing the distribution of the areas covered by nepheline syenite (after El-Ramly).
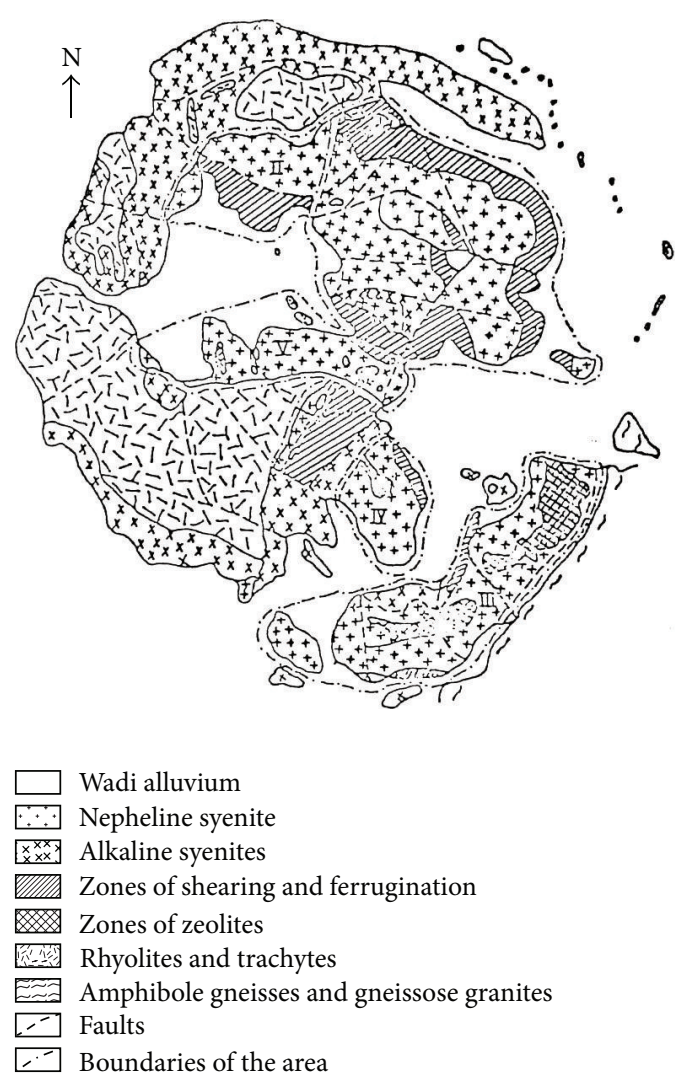

FIGURE 3: Sketch map of Gabal Abu Khruq showing the distribution of the areas covered by the different rock types (after El-Ramly). 
of soda and potash. The filtrated solids are used for cement production. Although this technology is successfully applied in Russia for utilizing their nepheline syenite ore, it does not seem to be an attractive route for Abu Khruq ore [4]. The reasons for this is that the reserves are not large enough for such huge complex plant; the proper type of limestone needed is about $800 \mathrm{~km}$ far from the Abu-Khruq site, and the average $\mathrm{Al}_{2} \mathrm{O}_{3}$ content in the Egyptian ore ranges from 17 to $18 \%$ and the average content of silica is high (56-59\%), whereas the Russian process for alumina extraction specifies an ore of not less than $22.5 \%$ alumina content and not more than $45 \%$ silica content [4].

In an attempt to upgrade the Abu-Khruq ore, Shaaban $[7,8]$ obtained a good concentrate by roasting and extraction (hydrometallurgy). Using gravity separation and heavy media separation techniques, Shaaban was not able to get a reasonable concentrate from Abu-Khruq nepheline syenite sample. Ibrahim [9] got a concentrate assaying 21\% $\mathrm{Al}_{2} \mathrm{O}_{3}$ using shaking tables fed with a classified product. By flotation technique, using an anionic collector (Aeropromoter 825, at dosage of up to $2.0 \mathrm{~kg} / \mathrm{t}$ ore) a concentrate assaying $20 \% \mathrm{Al}_{2} \mathrm{O}_{3}$ was obtained at the optimum conditions [10].

The above beneficiation work for Abu-Khruq nepheline syenite ore $[7,9,10]$ was done for the purpose of obtaining a grade suitable for the extraction of alumina using the Russian process. However, the concentrate grades were still lower than the specs required by the Russian technique with high iron and silica content.

In 1996, Mahmoud [11] used a dry high intensity induced roll magnetic separator to produce a nepheline syenite concentrate for ceramic industry. He was able to obtain a nonmagnetic concentrate assaying $0.5 \% \mathrm{Fe}_{2} \mathrm{O}_{3}$ from $\mathrm{Abu}$ Khruq nepheline syenite sample assaying 6.78\% $\mathrm{Fe}_{2} \mathrm{O}_{3}$. Ibrahim et al. [12] attempted several dry magnetic separation techniques to beneficiate some Egyptian nepheline syenite ores for industrial purposes. They obtained concentrates with assays ranging from $0.5 \%$ to $0.7 \% \mathrm{Fe}_{2} \mathrm{O}_{3}$. This level of iron content is still high for acceptable qualities of glass and ceramics products, which impose a limitation on the iron oxide content not to exceed $0.2 \% \mathrm{Fe}_{2} \mathrm{O}_{3}$.

This paper is concerned with the characterization and beneficiation of the nepheline syenite ore at Gabal AbuKhruq ring complex. The main characteristics of the ore which are investigated are mineralogical constituents, chemical composition, grain size range of the constituting minerals, their grain/grain interlocking, and the relative distribution of the useful and nonuseful constituents. The information gathered from the characterization studies will be the guide lines for the beneficiation program.

\section{Experimental Work}

Collection and Preparation of Ore Sample. After field investigation, a fresh sample, about 3 tons, was collected from a sampling adit intersecting the ore body. The adit was an exploratory opening opened by the Geological Survey of Egypt for evaluating the deposit. The collected sample was divided into two parts; one part was crushed and ground and the other part was saved as coarse lumps for further studies. Representative samples from the ground material were used for chemical analysis, size distribution, density determination, porosity, and mineral processing tests. Lumps from the coarse sample were used for petrography studies, crushing strength, and grindability tests [5].

\subsection{Characterization}

2.1.1. Mineralogy. The petrography investigation of the ore was carried out by polarizing microscope using thin sections and polished sections. Both scanning electron microprobe and $\mathrm{X}-\mathrm{RD}$ have also been used to support the mineral identification in the rock. Scanning Electron Microscope was used for spot testing of the sample to check the homogeneity of the distribution of the constituting elements in the ore sample.

2.1.2. Chemical Analysis. X-RF and wet chemical analysis techniques were used for the chemical analysis of the feed ample and concentration products. For simplicity, $\mathrm{Fe}_{2} \mathrm{O}_{3}$ was analyzed throughout the concentration experiments as an indication of the efficiency of iron removal in the concentration products. At optimum concentration conditions, all the important chemical constituents were analyzed for the final concentrate.

2.1.3. Physical and Mechanical Properties of the Ore. Density, porosity, and crushing strength were carried out using conventional techniques. A standard Bond ball mill (locked cycle test) was used to determine the Work Index of the ore in wet and dry grinding conditions.

2.1.4. Detection of Radioactive Elements. Gamma Ray Spectrometer (Gamma-Gamma Technique) was used for measuring the concentration of the radioactive elements (Uranium, Thorium, and Radon) [13]. In this method, the detector is well shielded by keeping it inside a lead brick chamber of $5 \mathrm{~cm}$ thick and lined with thin copper sheet to prevent the back scattering of the gamma rays. The counting time of 10 minutes is known to be enough time for samples giving more than 600 counts in this time period (10 minutes) which gives counting errors less than 5 percent. For samples with lower counting, longer counting period is used. In this latter case, fixed gamma ray counts of 10,000 counts are to be obtained to ensure that the counting error is below 5 percent $[13,14]$. After grinding to minus 200 mesh, samples were stored for at least 20 days to attain equilibrium. As a general rule, the activity of the standard sample must be less than double that of the sample under investigation.

\subsection{Beneficiation}

2.2.1. Magnetic Concentration. The induced roll magnetic separator, "Carpco," was used in this work as a free-fall type separator that is usually used for separating sand-size materials. The variables investigated in this research work are feed rate, field intensity, and feed size. The roll speed was kept 
constant at $60 \mathrm{rpm}$ and air gap was kept at $2 \mathrm{~mm}$ throughout the tests.

2.2.2. Flotation. A laboratory flotation machine, Denver \# D12, with one-liter tank, was used in this study. The collector used was Cyanamid Aeropromoter \#801 and \#825 at a ratio of $1: 1$. Conditioning time was taken as 5 minutes at rotor speed of $2500 \mathrm{rpm}$. The rotor speed was reduced to $1200 \mathrm{rpm}$ throughout the flotation test.

\section{Results and Discussion}

\subsection{Characterization}

3.1.1. Physical Properties of Abu Khruq Nepheline Syenite Ore. Tests were carried out on the head sample to determine the physical properties of the ore. The average values for these tests were

(i) compressive (crushing) strength $=875 \mathrm{~kg} / \mathrm{cm}^{2}$

(ii) true density $=3.05 \mathrm{~g} / \mathrm{cm}^{3}$

(iii) apparent density $=2.49 \mathrm{~g} / \mathrm{cm}^{3}$

(iv) packed bulk density $=1.5 \mathrm{~g} / \mathrm{cm}^{3}$

(v) porosity $=20 \%$.

These values indicate that the rock is compact and extremely hard. Of course these features have to be reflected on the grindability of the ore and on the specific energy consumption, and hence, on the economy of the size reduction operations (crushing and grinding) [15]. The Bond Work Index, which is an indication of the grindability of the ore, was calculated to be $26.2 \mathrm{kWh} / \mathrm{t}$ and $18.5 \mathrm{kWh} / \mathrm{t}$ for dry and wet grinding of the ore, respectively. These values are rather high compared with values for similar ores [16]. These high values of the work index confirm the high values of compressive strength obtained above.

3.1.2. Mineralogical Investigations of Abu Khruq Nepheline Syenite Ore. The investigation intended to characterize the mineral constituents of the ore, the grain size of each constituent, the mineral-mineral interactions, the degree of crystallinity of each mineral, the dissemination of some minerals in other mineral grains, and so forth.

Microscopically, the nepheline syenites are holocrystalline consisting essentially of orthoclase perthite, albite (An4), aegirite-augite, aegirite, nepheline, analcite, and secondary zeolites (Figures 4 and 5). The accessories are alkaline amphiboles, iron oxides, apatite and sphene. The nepheline syenites are medium to coarse grained. The light colored feldspar minerals range between $4.0 \mathrm{~mm}$ and $7.0 \mathrm{~mm}$ in length with some crystals reaching up to $1.0 \mathrm{~cm}$, and about 1.0 to $3.0 \mathrm{~mm}$ in width. The dark colored ferromagnesium minerals range between 2.0 and $4.0 \mathrm{~mm}$ long. Other laths, down to the micron size, have been identified within and along the peripheries of the abovementioned grown crystals. The average model percentages of the nepheline syenites

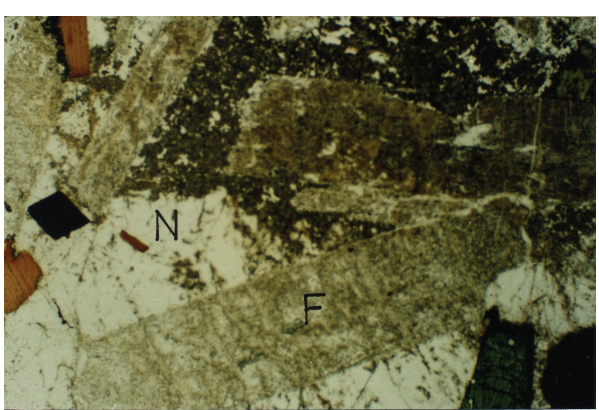

FIGURE 4: Microphotograph illustrating the orthoclase perthite crystals $(\mathrm{F})$ and altered nepheline $(\mathrm{N})$ with brown biotite, green Aegirine, and black iron oxides. Plane polarized light, x: 80 .

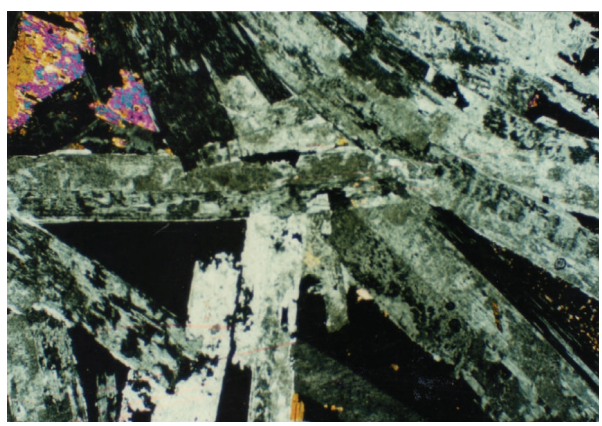

FIGURE 5: Microphotograph showing simple twinned orthoclase perthite and albite exhibiting polysynthetic twinning with isometric analcite and ferromagnesian minerals exhibiting moderate birefringence nepheline syenites. Crossed polars, $\mathrm{x}: 80$.

are $60-65 \%$ of the total mineral assemblage which is lightcolored alkali feldspars (potash feldspars and sodic plagioclase), the nepheline and analcite form about 5-15\%, and the dark colored mafics ferromagnesium minerals (pyroxenes and amphiboles) and iron oxides form about $20-25 \%$ of the total model percentage of the mineral assemblage.

The potash feldspar and sodic plagioclase (albite, An4) are the main constituents of the nepheline syenites (Figures 4 and 5). The potash feldspar is mainly the simple twinned orthoclase $\left(\mathrm{KAlSi}_{3} \mathrm{O}_{8}\right)$ which intergrows with the sodic plagioclase (albite) $\left(\mathrm{NaAlSi}_{3} \mathrm{O}_{8}\right)$ in the form of string and patchy perthitic intergrowths (Figure 5) The orthoclase perthite forms subhedral to anhedral crystals reaching up to $10.0 \mathrm{~mm}$ in length and $2.5 \mathrm{~mm}$ in breadth. Iron oxides and ferromagnesium granules are enclosed within feldspar crystals (Figure 4). The sodic plagioclase occurs also as subhedral prismatic crystals reaching up to $3.0 \mathrm{~mm}$ long and $1.0 \mathrm{~mm}$ in width. It is twinned according to Albite and combined Albite-Carlsbad laws. Nepheline, $\mathrm{Na}_{3}$ (Na, K) $\left(\mathrm{Al}_{4} \mathrm{Si}_{4} \mathrm{O}_{16}\right)$, forms anhedral to subhedral crystals corroding and replacing the early formed feldspars (Figure 4) and fills the triangular interstices between the feldspar crystals. It is partially altered to micaceous materials (sericite, zeolites, and cancrinites) (Figure 1). Apatite, feldspar, iron oxides, and ferromagnesium minerals are enclosed within the nepheline mineral. Analcite, $\mathrm{NaAl}\left(\mathrm{SiO}_{3}\right)_{2} \cdot \mathrm{H}_{2} \mathrm{O}$, forms anhedral 


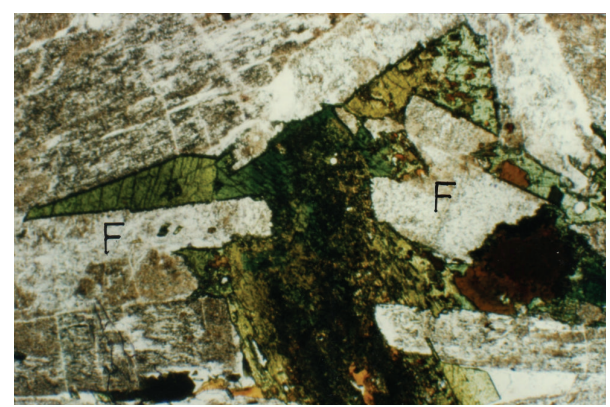

FIGURE 6: Microphotograph showing green colored aegirine subophitically enclosing feldspar crystals (F) and altered feldspar (turbid color) with brown biotite. Abu Khruq nepheline syenites, plane polarized light, $\mathrm{x}: 150$.

colorless masses invading and filling the triangular interstices between the feldspar crystals. It is commonly dark between crossed nicols (Figure 5). Analcite is commonly associated with nepheline and zeolites. Zeolites are commonly formed as irregular masses filling the triangular interstices between feldspar crystals and invading and replacing feldspars along the cleavage planes. Pyroxenes are represented mainly by aegirine-augite and aegirine (Figure 6). They form anhedral, subhedral, and euhedral prisms reaching up to $2.8-3 \mathrm{~mm}$ long. Aegirine is zoned and encloses aegirine-augite along its core. The pyroxene crystals enclose feldspar crystals in the form of ophitic and subophitic intergrowths. Biotite forms subhedral to anhedral flakes reaching up to $3.0 \mathrm{~mm}$ in length and $1.5 \mathrm{~mm}$ in breadth (Figure 4). It is strongly pleochroic from dark brown to reddish brown and exhibits straight extinction [11]. The ferrogenated nepheline syenite rock samples are characterized by red colors due to their staining by iron bearing solutions invading the rock body along the shear zones. Microscopic identification indicates that the hematitization of the feldspars and the ferrugination of the nepheline are especially along cleavage planes and fractures. It is worth mentioning that the mafic ferromagnesium minerals form 20-25 percent of the whole rock, with grain size reaching $3.0 \mathrm{~mm}$ in dimension, and interlocked with felsic minerals in a strong adhesive manner.

The electron microscope study [11] showed that the analyzed pyroxenes from Abu Khruq nepheline syenite are varying from aegirine-augite to aegirine exhibiting strong sodium enrichment accompanied by drastic depletion in calcium. This shows the paralkalinity of the magma from which the nepheline syenite came; that is, the evolution of the magma system is from alkali syenite to nepheline syenite, and which gave rise to the enrichment of the rocks in acmite and prevents their enrichment in hedenbergite [11]. The electron microscope showed also that biotite from Abu Khruq nepheline syenite is characterized by $\mathrm{TiO}_{2}$ from 2.63 to 4.09 percent, $\mathrm{MgO}$ up to 2.75 percent, $\mathrm{FeO}$ ranges between 35 and 39 percent, and $\mathrm{MnO}$ from 0.56 to 1.4 percent.

The conclusions of the mineralogical and petrography studies carried out on Abu Khruq nepheline syenite ore are the fact that, in addition to identifying the main mineral constituents of the ore necessary for the industry (such
TABLE 1: Average chemical analysis of Abu Khruq nepheline syenite head sample.

\begin{tabular}{lccc}
\hline Component & Percent & Component & Percent \\
\hline $\mathrm{SiO}_{2}$ & 60.23 & $\mathrm{MgO}$ & 0.52 \\
$\mathrm{TiO}_{2}$ & 0.33 & $\mathrm{CaO}$ & 1.04 \\
$\mathrm{Al}_{2} \mathrm{O}_{3}$ & 17.8 & $\mathrm{Na}_{2} \mathrm{O}$ & 8.52 \\
$\mathrm{Fe}_{2} \mathrm{O}_{3}$ (total) & 6.49 & $\mathrm{~K}_{2} \mathrm{O}$ & 6.01 \\
$\mathrm{FeO}$ & 0.66 & $\mathrm{P}_{2} \mathrm{O}_{5}$ & 0.29 \\
$\mathrm{MnO}$ & 0.16 & LOI & 1.22 \\
\hline
\end{tabular}

TABLE 2: Effect of feed rate to the Carpco induced roll magnetic separator.

\begin{tabular}{llccc}
\hline $\begin{array}{l}\text { Feed } \\
\text { rate, } \\
\mathrm{kg} / \mathrm{h}\end{array}$ & Product & $\begin{array}{c}\text { Product weight, } \\
\%\end{array}$ & $\begin{array}{c}\text { Assay, } \\
\mathrm{Fe}_{2} \mathrm{O}_{3} \%\end{array}$ & $\begin{array}{c}\text { Distribution, } \\
\mathrm{Fe}_{2} \mathrm{O}_{3} \%\end{array}$ \\
\hline \multirow{3}{*}{12} & Magnetic & 26.1 & 21.5 & 87.3 \\
& Nonmagnetic & 73.9 & 1.1 & 12.7 \\
& Total & 100 & 6.4 & 100 \\
\hline \multirow{3}{*}{24} & Magnetic & 24.7 & 20.5 & 81.7 \\
& Nonmagnetic & 75.3 & 1.5 & 18.3 \\
& Total & 100 & 6.2 & 100 \\
\hline \multirow{3}{*}{36} & Magnetic & 24.1 & 19.6 & 75.7 \\
& Nonmagnetic & 75.9 & 2.0 & 24.3 \\
& Total & 100 & 6.24 & 100 \\
\hline \multirow{3}{*}{48} & Magnetic & 27.3 & 16.5 & 70.4 \\
& Nonmagnetic & 72.7 & 2.6 & 29.6 \\
& Total & 100 & 6.4 & 100 \\
\hline
\end{tabular}

Particle size: $-0.25 \mathrm{~mm}$; Field intensity: 14500 Gauss.

as alkali feldspars, nepheline, and alkali pyroxenes and amphiboles), the petrography investigations revealed some important features which are essential in mineral processing. In general, the grain size of most of the ore constituents is relatively large and may reach up to $1.0 \mathrm{~cm}$ in dimension. On the other hand, the petrography analysis showed that some of the iron-bearing minerals are finely disseminated within the nepheline and alkali feldspar minerals, and some iron staining is intruded along cleavage planes and cracks of the desired minerals and smearing throughout some feldspar crystals and nepheline grains (Figures 1 and 2). The effect of these features may be reflected on the quality of the final concentrate. That is to say, there will be some limitations on the removal of the nondesired metallic constituents from the ore, and hence, the grade and recovery of the concentrate may be affected.

3.1.3. Chemical Analysis. Three samples obtained from the ground bulk of the original sample, the head sample, were analyzed by $\mathrm{X}-\mathrm{RF}$ and wet analyzing technique. Table 1 gives the average chemical analysis of Abu Khruq nepheline syenite head sample. It should be noted that the ore contains radioactive elements (uranium, thorium, and radon), which may be hazardous in some products. 
TABLE 3: Effect of the field intensity on the performance of the Carpco induced roll magnetic separator for cleaning the nepheline syenite ore.

\begin{tabular}{|c|c|c|c|c|c|}
\hline $\begin{array}{l}\text { Current intensity, } \\
\text { Ampere }\end{array}$ & Field intensity, Gauss & Product & Product weight, \% & Assay, $\mathrm{Fe}_{2} \mathrm{O}_{3} \%$ & Distribution, $\mathrm{Fe}_{2} \mathrm{O}_{3} \%$ \\
\hline \multirow{3}{*}{0.5} & \multirow{3}{*}{3,500} & Magnetic & 18.4 & 27.8 & 85.8 \\
\hline & & Nonmagnetic & 81.6 & 1.6 & 14.2 \\
\hline & & Total & 100 & 6.42 & 100 \\
\hline \multirow{3}{*}{1.0} & \multirow{3}{*}{7,100} & Magnetic & 21.1 & 25.2 & 91.1 \\
\hline & & Nonmagnetic & 78.9 & 1.4 & 8.9 \\
\hline & & Total & 100 & 6.43 & 100 \\
\hline \multirow{3}{*}{2.0} & \multirow{3}{*}{14,500} & Magnetic & 25.4 & 21.8 & 93.0 \\
\hline & & Nonmagnetic & 74.6 & 1.2 & 7.0 \\
\hline & & Total & 100 & 6.43 & 100 \\
\hline \multirow{3}{*}{3.0} & \multirow{3}{*}{18,000} & Magnetic & 27.2 & 20.5 & 94.9 \\
\hline & & Nonmagnetic & 73.2 & 1.1 & 5.1 \\
\hline & & Total & 100 & 6.35 & 100 \\
\hline
\end{tabular}

Feed size fraction: $-0.25 \mathrm{~mm}$; Feed rate, $\mathrm{kg} / \mathrm{h}: 24$.

\subsection{Beneficiation}

3.2.1. Magnetic Separation. As mentioned above, the Carpco induced roll magnetic separator was used for upgrading Abu Khruq nepheline syenite ore. The effects of feed rate, magnetic field intensity, and feed particle size were investigated. Other operating parameters were kept constant. Table 2 shows the effect of the feed rate to the separator. As the feed rate increases, the percentage of $\mathrm{Fe}_{2} \mathrm{O}_{3}$ in the nonmagnetic fraction increases, and the removal of the iron oxide in the magnetic fraction decreases. This is logical because the material bed thickness increases with increasing the feed rate, and hence, the attraction of the magnetic grains to the rotating roll is hindered. The feed rate to the separator for the following series was taken as $24 \mathrm{~kg} / \mathrm{t}$.

Table 3 presents the effect of the magnetic field intensity on the performance of the magnetic separator. As the field intensity increases the attraction of the magnetic particles to the roll increases, and hence, the nonmagnetic fraction gets cleaner as the magnetic field intensity increases. A field intensity of 14500 Gauss (2.0 Amperes) was used in the following series of experiments where the assay of the iron oxide in the nonmagnetic fraction was $1.2 \% \mathrm{Fe}_{2} \mathrm{O}_{3}$.

The effect of feed particle size on the performance of the magnetic separator is shown in Table 4. The information in Table 4 shows that the nonmagnetic fraction gets cleaner as the feed size fraction is finer. The iron assay in the nonmagnetic product reached as low as $0.52 \% \mathrm{Fe}_{2} \mathrm{O}_{3}$ from a feed assaying about $6.4 \% \mathrm{Fe}_{2} \mathrm{O}_{3}$. These improved results at the fine size are probably due to more liberation of the ironbearing minerals in the feed as the particle size is reduced. Although this result is a major improvement, the iron content in the concentrate is still higher than the specs required for glass and ceramics industry.

3.2.2. Flotation. Reverse anionic flotation technique was adopted to float the iron-bearing minerals from the nepheline syenite rock. Cyanamid Aeropromotor $(801+825$ at a ratio
1:1) was used as a collector, and Aerofroth $65(0.1 \mathrm{~kg} / \mathrm{t})$ was used as a frother. Table 5 shows that the optimum $\mathrm{pH}$, at which the concentrate has the minimum iron content, was $\mathrm{pH}$ 4. At this $\mathrm{pH}$, about $62 \%$ of the iron content in the rock was removed leaving a concentrate assaying $2.8 \% \mathrm{Fe}_{2} \mathrm{O}_{3}$. Table 6 shows the effect of the solids percent in the flotation media. As the solids percent gets higher the iron content in the concentrate increases because of higher particle crowding in the flotation cell. The cleanest concentrate was obtained at $10 \%$ solids, but the suspension under these conditions is too dilute. Suspensions containing 20\% solids were used for the next series of experiments where the iron removal in the froth was more than $63 \%$ of the iron content in the rock, about $6.4 \% \mathrm{Fe}_{2} \mathrm{O}_{3}$, and the iron oxide assay in the concentrate was $3.0 \% \mathrm{Fe}_{2} \mathrm{O}_{3}$. The effect of the collector dose on the flotation behavior of the iron bearing minerals can be seen in Table 7 . As the collector concentration increases cleaner concentrate is obtained. A concentrate assaying $0.7 \% \mathrm{Fe}_{2} \mathrm{O}_{3}$ was obtained at collector concentration of $3 \mathrm{~kg} / \mathrm{t}$. The iron removal in the froth, under these conditions, was over $92 \%$ of the iron content in the rock. Although this high reduction in iron content in the concentrate can be considered a remarkable success, the product is still of lower quality than the specs for glass and ceramics industry.

3.2.3. Magnetic Separation Followed by Flotation. The nonmagnetic product obtained under optimum conditions in magnetic separation was used as feed to the flotation cell. This product assayed $0.52 \% \mathrm{Fe}_{2} \mathrm{O}_{3}$, and $21.1 \% \mathrm{Al}_{2} \mathrm{O}_{3}$ containing $88.4 \%$ of the alumina in the nepheline syenite rock. The feed size distribution to the magnetic separator was $-125 \mathrm{~mm}$ material, and the magnetic field intensity was 14,500 Gauss (current to the electromagnetic coil 2.0 Amperes). The nonmagnetic product was ground to pass $0.074 \mathrm{~mm}$ and fed to the flotation cell at $20 \%$ solids, at $\mathrm{pH}$ value of 4 , conditioned for five minutes with $0.6 \mathrm{~kg} / \mathrm{t}$ Cyanamid collector (mixture of 801 and 825 at a ratio of $1: 1), 0.5 \mathrm{~kg} / \mathrm{t}$ sodium silicate for dispersion, followed by one more minute conditioning 
TABLE 4: Effect of feed size fraction of the nepheline syenite ore on the performance of the Carpco Induced Roll Magnetic separator.

\begin{tabular}{|c|c|c|c|c|}
\hline Feed size & Product & Product weight, $\%$ & Assay, $\mathrm{Fe}_{2} \mathrm{O}_{3} \%$ & Distribution, $\mathrm{Fe}_{2} \mathrm{O}_{3} \%$ \\
\hline \multirow{3}{*}{$-0.25 \mathrm{~mm}$} & Magnetic & 25.1 & 21.2 & 82.5 \\
\hline & Nonmagnetic & 74.9 & 1.5 & 17.5 \\
\hline & Total & 100 & 6.45 & 100 \\
\hline \multirow{3}{*}{$-0.16 \mathrm{~mm}$} & Magnetic & 25.8 & 22.5 & 89.7 \\
\hline & Nonmagnetic & 74.2 & 0.91 & 10.3 \\
\hline & Total & 100 & 6.48 & 100 \\
\hline \multirow{3}{*}{$-0.125 \mathrm{~mm}$} & Magnetic & 23.7 & 25.1 & 93.7 \\
\hline & Nonmagnetic & 76.3 & 0.52 & 6.3 \\
\hline & Total & 100 & 6.36 & 100 \\
\hline
\end{tabular}

Feed rate: $24 \mathrm{~kg} / \mathrm{h}$; Field intensity: 14500 Gauss.

TABLE 5: Effect of the $\mathrm{pH}$ value on the flotation behavior of $\mathrm{Abu}$ Khruq nepheline syenite ore. The feed size is -0.125 micron.

\begin{tabular}{ccccc}
\hline Solution pH Product & $\begin{array}{c}\text { Product Wt., } \\
\%\end{array}$ & $\begin{array}{c}\text { Assay, } \\
\mathrm{Fe}_{2} \mathrm{O}_{3} \%\end{array}$ & $\begin{array}{c}\text { Distribution, } \\
\mathrm{Fe}_{2} \mathrm{O}_{3} \%\end{array}$ \\
\hline \multirow{3}{*}{3} & Froth & 12.5 & 28.5 & 55.7 \\
& Bulk & 87.5 & 3.25 & 44.3 \\
& Total & 100 & 6.4 & 100 \\
\hline \multirow{3}{*}{5} & Froth & 15.0 & 26.1 & 62.2 \\
& Bulk & 85.0 & 2.8 & 37.8 \\
& Total & 100 & 6.3 & 100 \\
\hline \multirow{3}{*}{6} & Froth & 22.0 & 16.7 & 60.6 \\
& Bulk & 78.0 & 3.1 & 39.4 \\
& Total & 100 & 6.12 & 100 \\
\hline
\end{tabular}

Collector dose: $0.6 \mathrm{~kg} / \mathrm{t}$; Solids in slurry: $20 \%$.

TABLE 6: Effect of solids percent on the anionic reverse flotation of Abu Khruq nepheline syenite ore. The feed size is -0.125 micron.

\begin{tabular}{llccc}
\hline $\begin{array}{l}\text { Solids, } \\
\text { percent }\end{array}$ & Product & $\begin{array}{c}\text { Product Wt., } \\
\%\end{array}$ & $\begin{array}{c}\text { Assay, } \\
\mathrm{Fe}_{2} \mathrm{O}_{3} \%\end{array}$ & $\begin{array}{c}\text { Distribution, } \\
\mathrm{Fe}_{2} \mathrm{O}_{3} \%\end{array}$ \\
\hline \multirow{3}{*}{10} & Froth & 23.2 & 18.5 & 65.8 \\
& Bulk & 76.89 & 2.9 & 34.2 \\
& Total & 100 & 6.52 & 100 \\
\hline \multirow{3}{*}{20} & Froth & 22.3 & 18.0 & 63.3 \\
& Bulk & 77.7 & 3.0 & 36.7 \\
& Total & 100 & 6.35 & 100 \\
\hline \multirow{3}{*}{30} & Froth & 16.4 & 16.8 & 43.5 \\
& Bulk & 83.6 & 4.3 & 56.5 \\
& Total & 100 & 6.34 & 100 \\
\hline
\end{tabular}

pH value: 4; Collector dose: $0.5 \mathrm{~kg} / \mathrm{t}$.

with $0.1 \mathrm{~kg} / \mathrm{t}$ Aerofroth 65 . The flotation test was ended when the froth became barren. The final nepheline syenite concentrate assayed $0.2 \% \mathrm{Fe}_{2} \mathrm{O}_{3}$ and $23.9 \% \mathrm{Al}_{2} \mathrm{O}_{3}$ at a total alumina recovery of $80.2 \%$ (Table 8 ). This product proved
TABle 7: Effect of collector dose (Cyanamid) on the flotation response of Abu Khruq nepheline syenite ore. The feed size is -0.125 micron.

\begin{tabular}{llccc}
\hline $\begin{array}{l}\text { Collector dose, } \\
\mathrm{kg} / \mathrm{t}\end{array}$ & Product & $\begin{array}{c}\text { Product Wt., } \\
\%\end{array}$ & $\begin{array}{c}\text { Assay, } \\
\mathrm{Fe}_{2} \mathrm{O}_{3} \%\end{array}$ & $\begin{array}{c}\text { Distribution, } \\
\mathrm{Fe}_{2} \mathrm{O}_{3} \%\end{array}$ \\
\hline \multirow{3}{*}{0.5} & Froth & 22.3 & 18.2 & 64.3 \\
& Bulk & 77.7 & 2.9 & 35.7 \\
& Total & 100 & 6.34 & 100 \\
\hline \multirow{3}{*}{1} & Froth & 25.1 & 20.3 & 80.0 \\
& Bulk & 74.9 & 1.7 & 20 \\
& Total & 100 & 6.37 & 100 \\
\hline \multirow{3}{*}{2} & Froth & 27.4 & 20.8 & 87.7 \\
& Bulk & 72.6 & 1.1 & 12.3 \\
& Total & 100 & 6.5 & 100 \\
\hline \multirow{3}{*}{3} & Froth & 31.5 & 19.1 & 92.6 \\
& Bulk & 68.5 & 0.7 & 7.4 \\
& Total & 100 & 6.5 & 100 \\
\hline
\end{tabular}

pH value: 4 ; Solids in slurry: $20 \%$.

to be suitable for the production of white glass ware and high quality sanitary products [5]. The high-iron content products were tested for glassceramics production and acid resistant tiles, and the products were satisfactory for these purposes [5]. This makes all the products from the nepheline syenite beneficiation plant industrially useful for producing high quality glass and ceramics products as well as other useful products without waste rejection, which is also an additional advantage for environmental preservation. Based on the mineralogical investigation for this type of ore, it seems that it cannot be cleaned further. The reason for this conclusion is that there are some nepheline syenite crystals which are impregnated with iron solutions within the crystal matrix. This type of iron contamination could not be removed with physical processes.

3.2.4. Distribution of Radioactive Elements. The radioactive hazardous elements (uranium, thorium, and radon) were followed up in various products throughout the experimental program. It was found that the percentage of these elements increase as the iron oxide increases in the product, and 
TABLE 8: Magnetic separation followed by reverse anionic flotation.

\begin{tabular}{|c|c|c|c|c|c|c|}
\hline \multirow{2}{*}{ Separation step } & \multirow{2}{*}{ Product } & \multirow{2}{*}{ Product Wt., \% } & \multicolumn{2}{|c|}{ Assay } & \multicolumn{2}{|c|}{ Distribution } \\
\hline & & & $\mathrm{Fe}_{2} \mathrm{O}_{3}, \%$ & $\mathrm{Al}_{2} \mathrm{O}_{3}, \%$ & $\mathrm{Fe}_{2} \mathrm{O}_{3}, \%$ & $\mathrm{Al}_{2} \mathrm{O}_{3}, \%$ \\
\hline \multirow{3}{*}{$\begin{array}{l}\text { Magnetic Sep. Step } \\
(-0.125 \mathrm{~mm} \text { feed size })\end{array}$} & Magnetic & 23.7 & 25.1 & 8.1 & 93.7 & 11.64 \\
\hline & Nonmag. & 76.3 & 0.52 & 21.1 & 6.3 & 88.36 \\
\hline & Total & 100 & 6.49 & 18.1 & 100 & 100 \\
\hline \multirow{3}{*}{$\begin{array}{l}\text { Flotation Step } \\
(-0.074 \mathrm{~mm} \text { feed size })\end{array}$} & Froth & $20.5(15.6)^{*}$ & 1.8 & 10.2 & $69.9(4.33)^{*}$ & $9.9(8.2)^{*}$ \\
\hline & Bulk & $79.5(60.7)^{*}$ & 0.2 & 23.9 & $30.1(1.86)^{*}$ & $90.2(80.2)^{*}$ \\
\hline & Total & $100(76.3)^{*}$ & 0.53 & 21.1 & $100(6.3)^{*}$ & $100(88.4)^{*}$ \\
\hline
\end{tabular}

*Values in parentheses are calculated based on the head sample.

TABLE 9: Concentration of the hazardus elements as a function of the iron assay of the product. The concentration of the radioactive minerals are in part per million (PPM).

\begin{tabular}{lccc}
\hline \multirow{2}{*}{ Element } & \multicolumn{3}{c}{ Product iron assay } \\
& $0.5 \% \mathrm{Fe}_{2} \mathrm{O}_{3}$ & $13 \% \mathrm{Fe}_{2} \mathrm{O}_{3}$ & $6.5 \% \mathrm{Fe}_{2} \mathrm{O}_{3}$ (Feed) \\
\hline Uranium & 1.8 & 3.9 & 2.5 \\
Thorium & 9.3 & 17.4 & 13.0 \\
Radon & 10.5 & 15.3 & 11.5 \\
\hline
\end{tabular}

vice versa. Table 9 shows the concentration in PPM of the hazardous elements at different iron concentrations in the various products. The uranium concentration decreases from 2.8 PPM to 1.8 PPM, thorium decreases from $13 \mathrm{PPM}$ to 9.3 PPM, and radon decreases from 11.5 PPM to $10.5 \mathrm{PPM}$ as the iron assay decreased from $13.2 \% \mathrm{Fe}_{2} \mathrm{O}_{3}$ to $0.5 \%$ $\mathrm{Fe}_{2} \mathrm{O}_{3}$. These results show that the radioactive minerals are associated in this rock with the iron-bearing minerals. It also shows that the content of the radioactive elements in the nepheline syenite concentrate has been reasonably decreased, which is an additional merit for the beneficiation of this rock.

\section{Summary and Conclusions}

The nepheline syenite ore under consideration has been characterized and concentrated with the aim to produce a high quality concentrate having high alumina content and the lowest possible iron content. The following findings have been confirmed.

(1) The ore is dense, compact, and exceptionally hard. Its compressive strength is around $875 \mathrm{~kg} / \mathrm{cm}^{2}$. The Bond Work Index is about $26 \mathrm{kWh} / \mathrm{t}$ and $18 \mathrm{kWh} / \mathrm{t}$ for dry and wet grinding, respectively.

(2) The ore consists of orthoclase perthite, albite, aegiriteaugite, aegirite, nepheline, analcite, and secondary zeolites. The accessories are alkaline amphiboles, iron oxides, apatite, sphene, and pyroxenes. The grain size of most of the ore constituents is relatively large.

(3) In some samples, the ferrogenated nepheline syenite samples, the iron oxides fill minor cracks and cleavage planes of the useful mineral constituents, which may impose limitations on the grade and/or recovery of the useful mineral constituents by physical processing operations.

(4) By a combination of magnetic separation and reverse anionic flotation, a nepheline syenite concentrate assaying $0.2 \% \mathrm{Fe}_{2} \mathrm{O}_{3}$ and $23.9 \% \mathrm{Al}_{2} \mathrm{O}_{3}$ was obtained. Furthermore, the radioactive elements (uranium, thorium, and radon) decreased to some extent with decreasing the iron content of the products, that is, the nepheline syenite concentrate for high quality glass and ceramics contained lowest concentrations of these hazardous elements than the feed. These results show clear indications for successful beneficiation and positive environmental effects.

\section{Conflict of Interests}

The authors declare that there is no conflict of interests regarding the publication of this paper.

\section{References}

[1] G. R. Guillet, "Nepheline syenite," The Industrial Minerals and Rocks Handbook, pp. 711-730, 1994.

[2] P. W. Harben, "World distribution of industrial mineral deposits," The Industrial Minerals Handbook, pp. 15-31, 1995.

[3] F. M. El-Ramly, "The three ring complexes of Gabal El-Kahfa, Gabal Nigrub El-Fogani, and Gabal El-Naga," A publication of the Geological Survey of Egypt, 1969.

[4] M. F. El-Ramly, N. E. Dereniuk, and L. K. Armanius, "Assessment and technological testing of the nepheline syenite of Gabal Abu-Khruq," A publication of the Gealogical Survey of Egypt, 1970.

[5] A.-T. A. Negm, A. Z. M. Abouzeid, and H. T. Abuzeid, "Processing of nepheline syenite for glass and ceramic industries," Tech. Rep., The Academy of Scientific Research and Technology, Cairo, Egypt, 2001.

[6] J. R. Vail, "Ring complexes and related rocks in Africa," Journal of African Earth Sciences, vol. 8, no. 1, pp. 19-40, 1989.

[7] A. S. Shaaban, "Suitability of some Egyptian limestone for the processing of nepheline syenite," A publication of the Geological Survey of Egypt, 1968.

[8] A. S. Shaaban, "Report on the processing of Egyptian nepheline syenite roks: a semipilot investigation of the leaching process," A publication of the Geological Survey of Egypt, 1970. 
[9] G. A. A. Ibrahim, Studies on some of the problems of the production of alumina in Egypt [M.S. thesis], The Department of Mining and Metallurgy, Faculty of Engineering, University of Assiut, Assiut, Egypt, 1971.

[10] M. Z. Hathout, M. M. El-Gendy, and G. A. Ibrahim, "Upgrading of the alumina in the Egyptian nepheline syenite," The Bulletin of Faculty of Engineering, Assiut University, vol. 1, part 1, 1973.

[11] M. H. Mahmoud, The mineralogy of some Egyptian alkaline rocks, beneficiation and utilization in ceramic industry [Ph.D. thesis], Department of Chemistry, Faculty of Science, Cairo University, Giza, Egypt, 1996.

[12] S. S. Ibrahim, H. A. Mohamed, and T. R. Boulos, "Dry magnetic separation of nepheline syenite ores," Physicochemical Problems of Mineral Processing, vol. 36, pp. 173-183, 2002.

[13] A. H. Hussien, Geochemistry of granitic rock and uranium mineralization in ElMissikat-ElFrediya Area, South-West Safaga, Eastwrn Desert, Egypt [Ph.D. thesis], Department of Geology, Faculty of Science, Cairo University, Giza, Egypt, 1987.

[14] H. Faul, Nuclear Geology, John Wiley and Sons, New York, NY, USA, 1954.

[15] H. A. Ahmed, Benificiation of some Egyptian nepheline syenite ores for ceramics and glass industries [M.S. thesis], Department of Mining Engineering, Faculty of Engineering, Cairo University, Giza, Egypt, 1998.

[16] O. Y. Gulsoy, S. L. Ergun, and S. Kulaksiz, "Benrficiation of nepheline syenite in Turkey," in Mining, Petroleum, and Metallurgical Conference, Assiut University, Assiut, Egypt, 1994. 

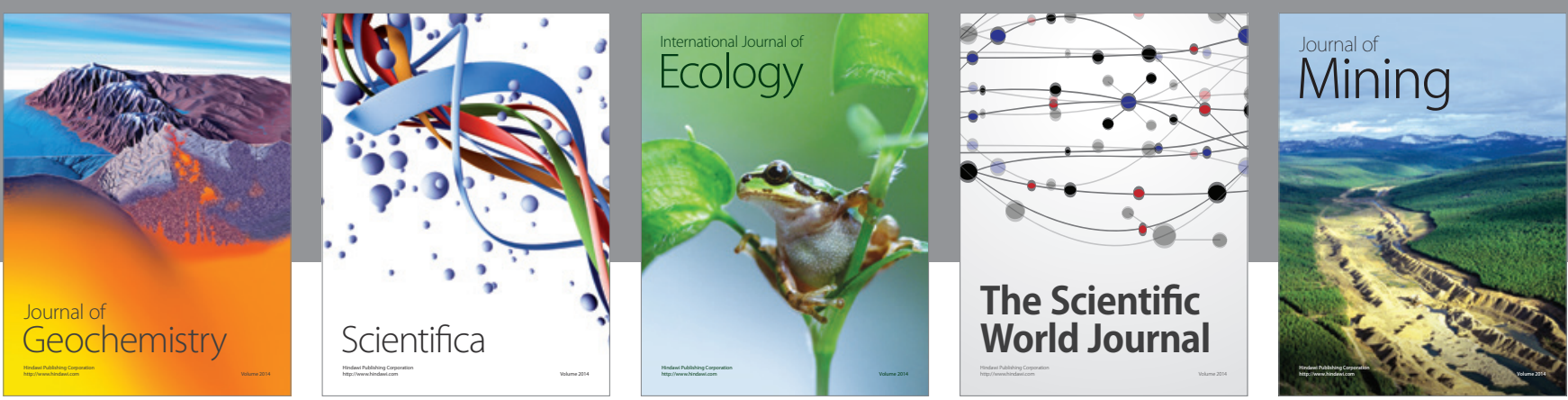

The Scientific World Journal
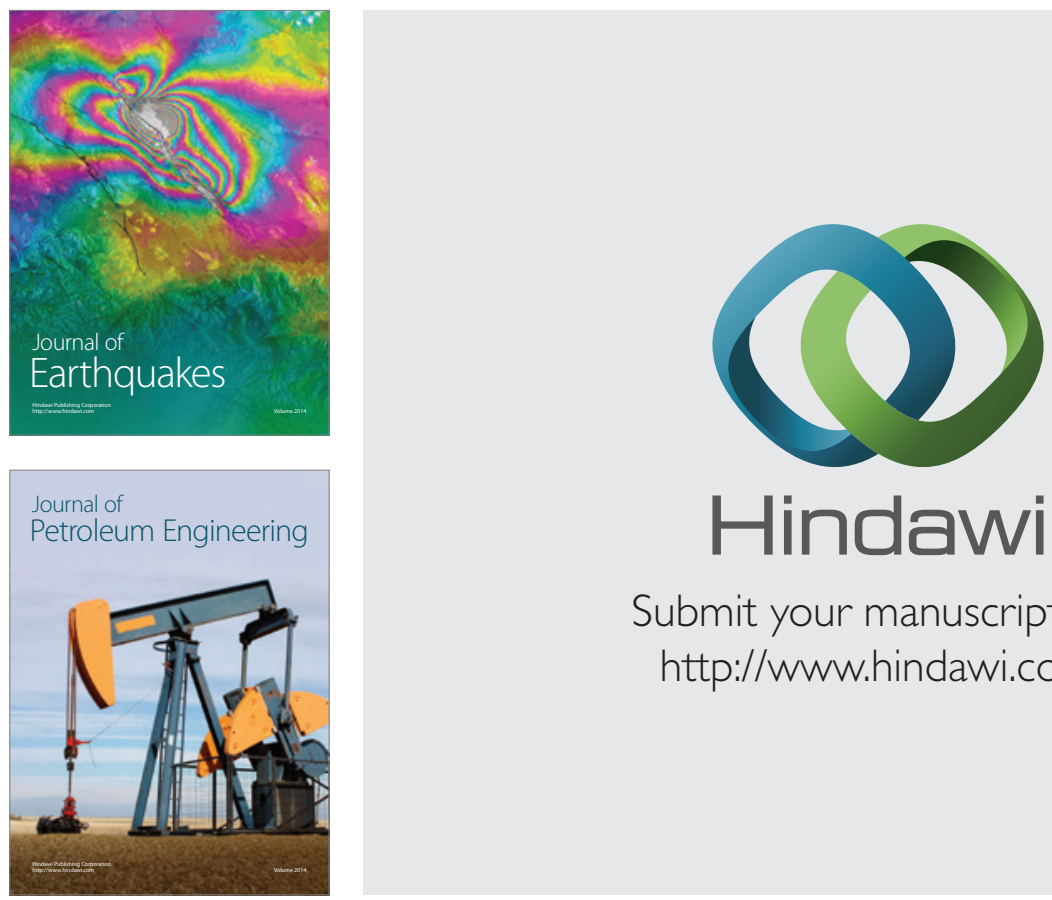

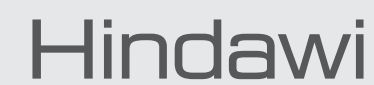

Submit your manuscripts at

http://www.hindawi.com
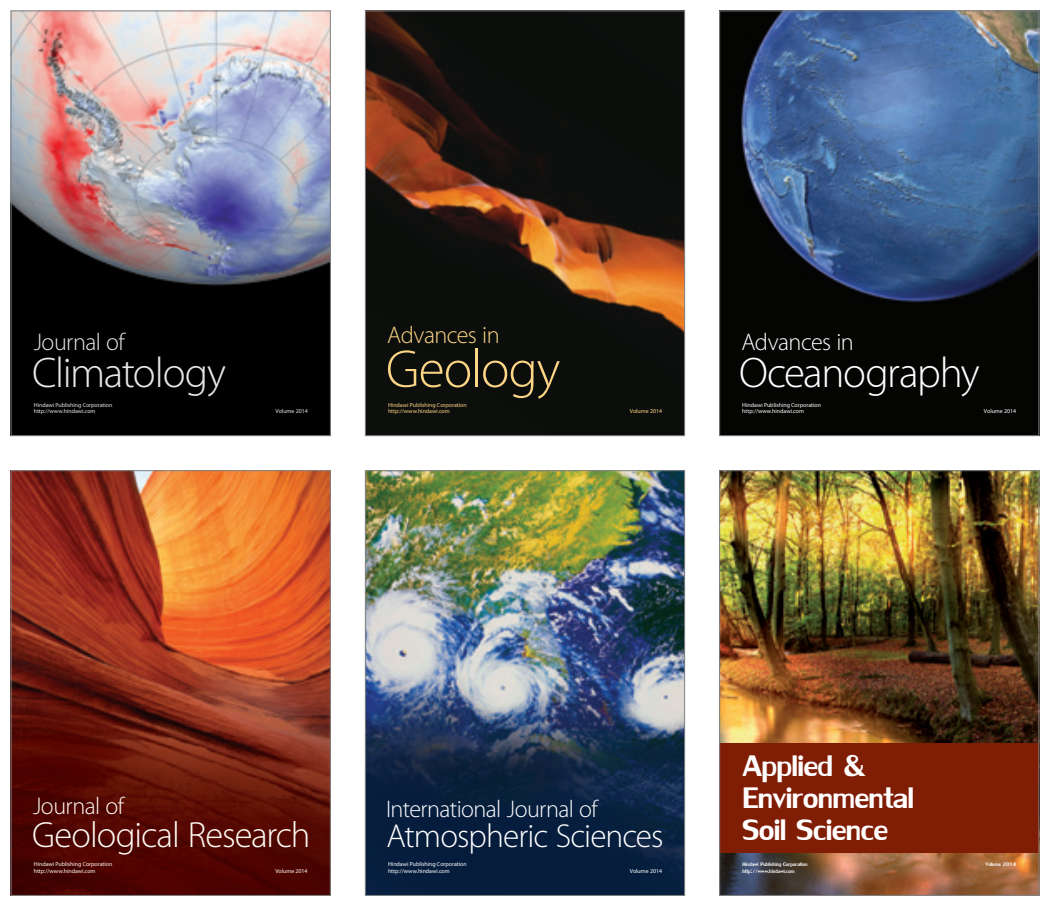
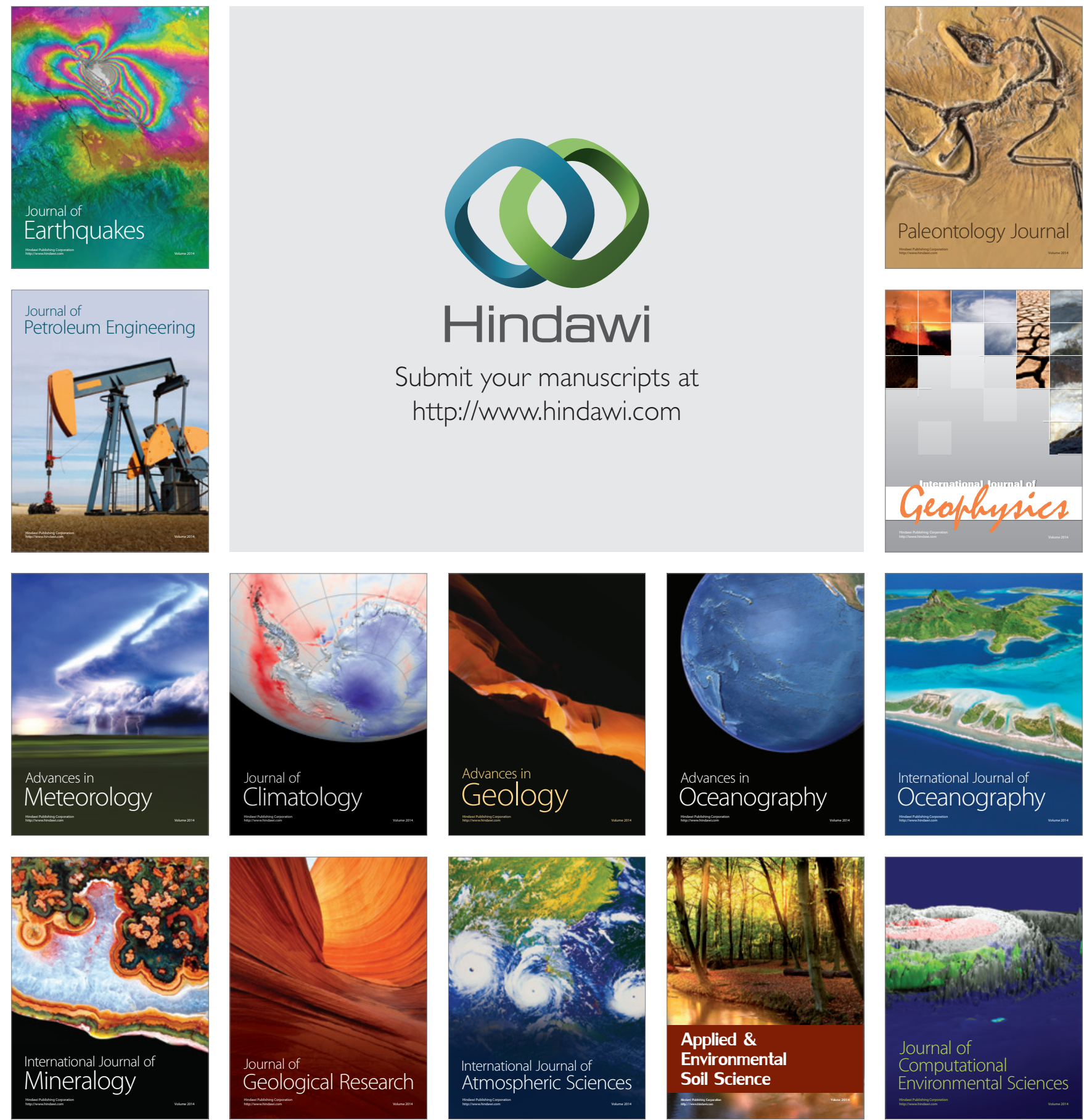